Færre diabetikere får senkomplikasjoner

Forekomsten av alvorlige senkomplikasjoner som hjerteinfarkt og slag har gått ned blant amerikanske diabetikere. Dette viser en nylig publisert studie.

I løpet av perioden 1990-2010 tredoblet antall voksne amerikanere med diagnosen diabetes mellitus seg, fra 6,5 millioner til 20,7 millioner. Risikoen for å få komplikasjoner relatert til sykdommen gikk imidlertid ned.

Andelen diabetikere som fikk akutt hjerteinfarkt gikk ned med 67,8\% (95\% KI $76,2-59,3)$. Den relative forekomsten av slag og ikke-traumatisk amputasjon av underekstremitet blant diabetikere ble halvert, og var i 2010 nede i henholdsvis 52,9 slagtilfeller og 28,4 tilfeller av amputasjon per 10000 diabetikere. I 1990 var hjerteinfarkt den mest utbredte av de undersøkte komplikasjonene, med 141,1 tilfeller per 10000 diabetikere. I 2010 var det omtrent like mange tilfeller av hjerteinfarkt som av slag.

Forekomsten av dialyse- eller transplantasjonskrevende nyresvikt blant diabetikere ble redusert gjennom studieperioden, men ikke i like stort omfang som for de andre komplikasjonene.

- Store intervensjonsstudier har vist at god blodsukkerregulering og bruk av antihypertensiver og statiner kan forebygge mikro- og makrovaskulære komplikasjoner hos diabetikere. $\mathrm{HbA}_{1 \mathrm{c}}$-verdier og medikamentbruk er ikke rapportert i denne registerstudien, sier endokrinolog Trine Finnes ved Sykehuset Innlandet, Hamar.

- Forfatterne viser imidlertid at den relative raten av hjerteinfarkt, slag, amputasjoner og alvorlig kronisk nyresvikt er redusert hos diabetikere sammenliknet med bakgrunnsbefolkningen. Dette tyder på at endringene har sammenheng med bedret diabetesbehandling.

- Økningen i antall diabetikere gjør at det absolutte antallet diabetikere med senkomplikasjoner fortsatt øker. Dette er viktig informasjon for å dimensjonere helsetilbudene. Amerikanske tall er ikke direkte overførbare til norske forhold, og det er derfor viktig at vi her i Norge implementerer diabetesregisteret for voksne som et obligatorisk register for en voksende pasientgruppe som vil kreve mye ressurser de neste tiårene, sier Finnes.

\section{Matilde Risopatron Berg}

Sykehuset Innlandet, Hamar

\section{Litteratur}

1. Gregg EW, Li Y, Wang J et al. Changes in diabetesrelated complications in the United States,

1990-2010. N Engl J Med 2014; 370: 1514-23.

\title{
Overvektige barn i Latin-Amerika
}

\author{
Overvekt og fedme er utbredt blant barn og unge i latinamerikanske
} land, til tross for at underernæring eksisterer i de samme områdene.

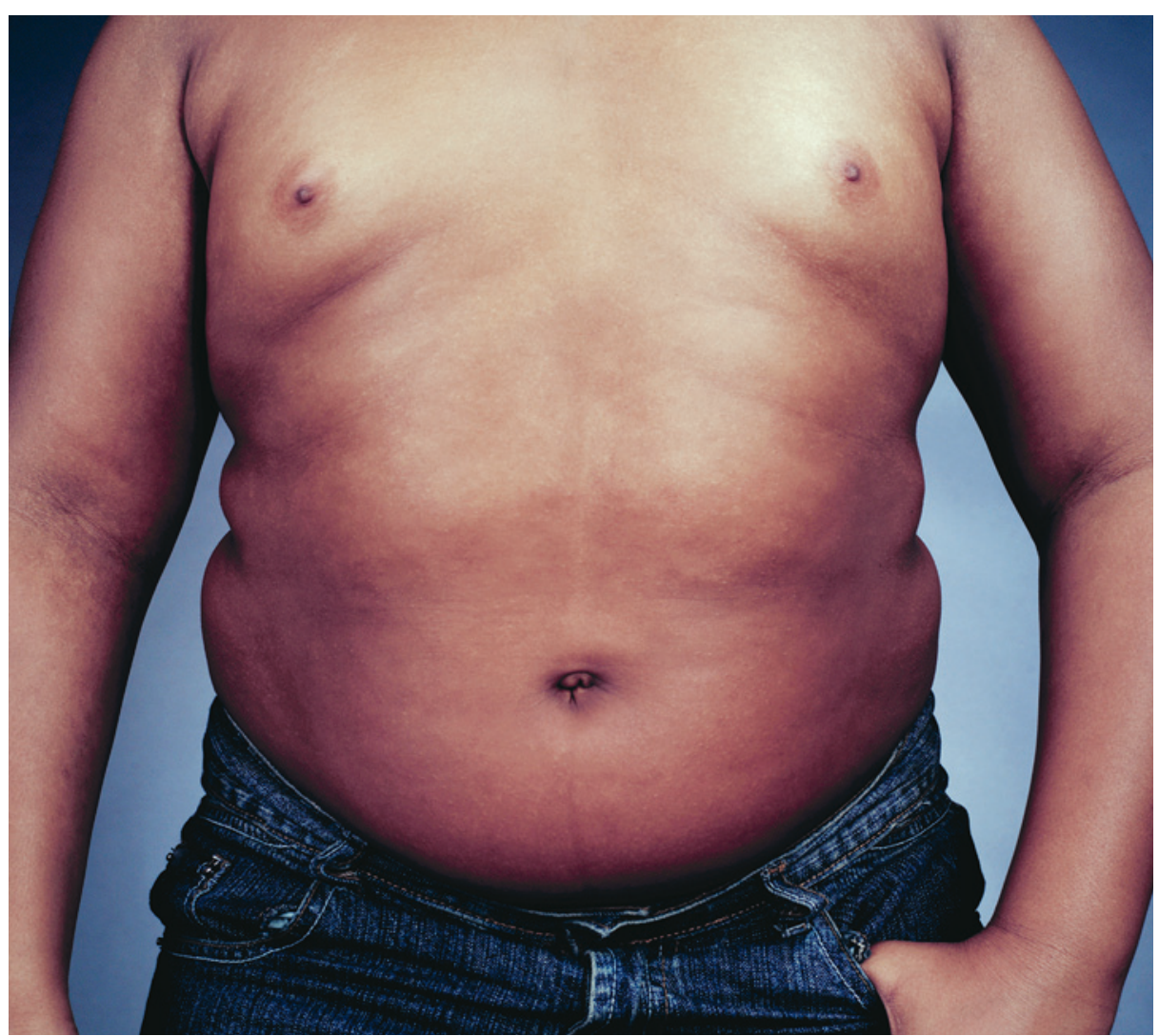

Illustrasjonsfoto: NTB scanpix

I en systematisk oversiktsartikkel er prevalensen av overvekt og fedme blant barn og unge i Latin-Amerika beregnet (1). Oversiktsartikkelen er basert på 42 tverrsnittsstudier fra Argentina, Brasil, Chile, Colombia, Mexico og Peru.

I aldersgruppen 0-5 år ble vekt-høydeforholdet brukt som mål for overvekt og fedme, og prevalensen ble beregnet til 7,1\% (95\% KI 6,2-8,0\%). Blant barn i alderen 5-11 år ble kroppsmasseindeks brukt som mål, og prevalensen av overvekt og fedme varierte fra $18,9 \%$ i Colombia til $36,9 \%$ i Mexico. Colombia hadde også lavest prevalens i aldersgruppen 12-19 år, med 16,6\%.

Med utgangspunkt i de 42 studiene som ble inkludert, er det beregnet at hvert 4-5 barn i Latin-Amerika har overvekt eller fedme. Det tilsvarer 42,5-51,8 millioner barn og unge i alderen $0-19$ år.

- Denne oversiktsartikkelen viser at overvekt og fedme er et stort problem i LatinAmerika, sier barnelege Pétur B. Júlíusson ved Haukeland universitetssykehus.
- Et generelt problem er at definisjonene for overvekt og fedme varierer mellom studiene. Studier fra Brasil og Mexico som inngår i oversiktsartikkelen bruker de samme definisjonene som vi har brukt i Norge (International Obesity Task Force, IOTF). I disse studiene ble det registrert en prevalens som er dobbelt så høy som den vi har i Norge, påpeker Júlíusson.

- De fleste av disse landene er i den spesielle situasjon at de har en samtidig forekomst av både under- og overernæring. Som forfatterne påpeker, så er underernæring i tidlig alder en risikofaktor for senere utvikling av overvekt, sier Júlíusson.

\section{Matilde Risopatron Berg}

Sykehuset Innlandet, Hamar

\section{Litteratur}

1. Rivera JA, de Cossío TG, Pedraza LS et al. Childhood and adolescent overweight and obesity in Latin America: a systematic review. Lancet Diabetes Endocrinol 2014; 2: 321-32. 